ANL-7014

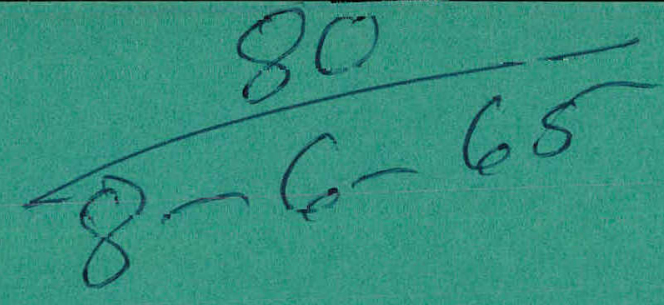

ANL-7014

Argonne ユational Laboratom

AN ANALYSIS OF

SIX AETR FAST CRITICAL EXPERIMENTS

by

William G. Davey

\begin{tabular}{|c|}
\hline Argonne Rational Laboratory \\
AN ANALYSIS OF \\
SIX AETR FAST CRITICAL EXPERIMENTS \\
by \\
William G. Davey \\
\hline
\end{tabular}




\section{DISCLAIMER}

This report was prepared as an account of work sponsored by an agency of the United States Government. Neither the United States Government nor any agency Thereof, nor any of their employees, makes any warranty, express or implied, or assumes any legal liability or responsibility for the accuracy, completeness, or usefulness of any information, apparatus, product, or process disclosed, or represents that its use would not infringe privately owned rights. Reference herein to any specific commercial product, process, or service by trade name, trademark, manufacturer, or otherwise does not necessarily constitute or imply its endorsement, recommendation, or favoring by the United States Government or any agency thereof. The views and opinions of authors expressed herein do not necessarily state or reflect those of the United States Government or any agency thereof. 


\section{DISCLAIMER}

Portions of this document may be illegible in electronic image products. Images are produced from the best available original document. 


\section{LEGAL NOTICE}

This report was prepared as an account of Government sponsored work. Neither the United States, nor the Commission, nor any jei sun acting on bohalf of the Commission:

A. Makes any warranty or representation, expressed or implied, with respect to the accuracy, completeness, or usefulness of the information contained in this report, or that the use of any information, apparatus, method, or process disclosed in this report may not infringe privately owned rights; or

B. Assumes any liablilles with rcopoot to the use of, or for damages resulting from the use of any information, apparatus, method, or process disclosed in this report.

As used in the above, "person acting on velualf of the Commigeinn" inclunes any employee or contractor of the Commission, or employee of such contractor, to the extent that such employee or contractor of the Commission, or employee of such contractor prepares, disseminates, or provides access to, any information pursuant to his employment or contract with the Commission, or his employment with such contractor.

Printed in USA. Price $\$ 1.00$. Available from the Clearinghouse for Federal Scientific and Technical Information, National Bureau of Standards, U. S. Department of Commerce, Springfield, Virginia 
ANL-7014

Reactor Technology (TID-4500, 43rd Ed.)

AEC Research and

Development Report

ARGONNE NATIONAL LABORATORY

9700 South Cass Avenue

Argonne, Illinois 60440

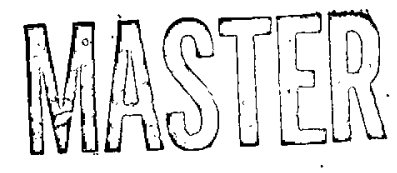

AN ANALYSIS OF

SIX AETR FAST CRITICAL EXPERIMENTS

by

William G. Davey

Idaho Division

March 1965

Operated by The University of Chicago under

Contract W-3l-109-eng-38

with the

U. S. Atomic Energy Commission 
TABLE OF CONTENTS

\begin{abstract}
Page

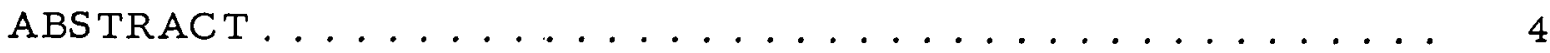

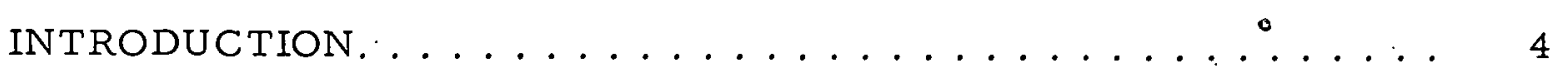

DESCRIPTION OF THE ASSEMBLIES STUDIED. . . . . . . . 6
\end{abstract}

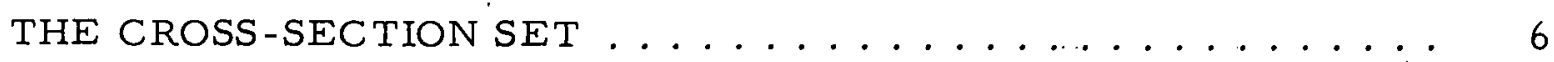

CALCULATION OF THE TEST REGION SPECTRA. . . . . . . 6

ANALYSIS OF FISSION RATIOS $\ldots \ldots \ldots \ldots \ldots$

ANALYSIS OF REACTIVITY DATA ................. 11

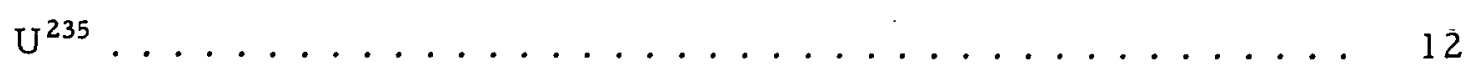

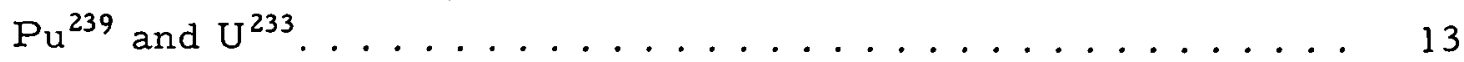

The Absorbers $\left(\mathrm{Th}^{232}, \mathrm{U}^{238}, \mathrm{~B}^{10}, \mathrm{Ta}, \mathrm{Mo}\right.$, and $\left.\mathrm{Nb}\right) \ldots \ldots 14$

The Scatterers $(\mathrm{Zr}$, Steel, $\mathrm{C}, \mathrm{Na}$, and $\mathrm{Al}) \ldots \ldots \ldots 17$

Comparison with ZPR-III Measurements .............. 17

ANALYSIS OF THE SOURCE IMPORTANCE MEASUREMENTS. . . . 20

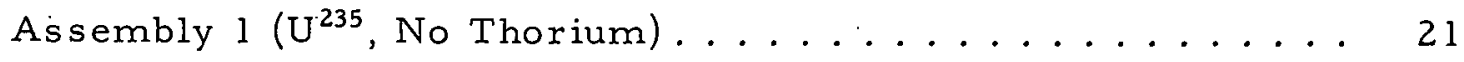

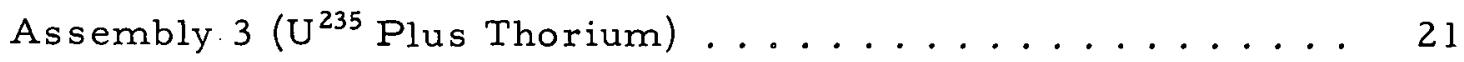

Assemblies $5,2,8$, and 9 (U $\mathrm{U}^{233}$ Plus Thorium) ....... 21

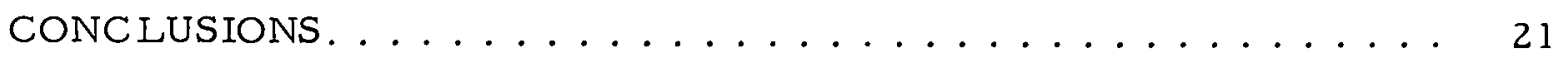

ACKNOWLEDGMENTS ....................... 22

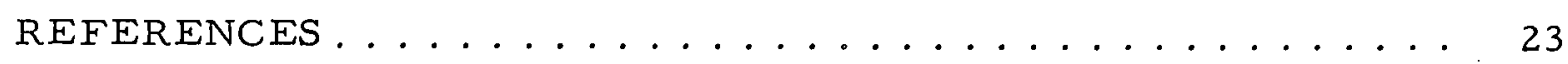




\section{LIST OF TABLES}

No.

Title

Page

I. Compositions and Dimensions of AETR Test Regions ..... 6

II. Calculated Real and Adjoint Spectra. ............ 7

III. Calculated and Experimental $\mathrm{Pu}^{239} / \mathrm{U}^{235}$ and $\mathrm{U}^{233} / \mathrm{U}^{235}$ Fission

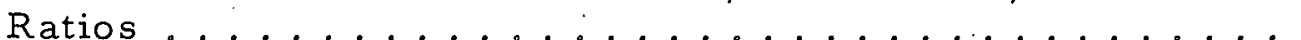

IV. Calculated and Experimental $\mathrm{U}^{234} / \mathrm{U}^{235}$ and $\mathrm{Np}^{237} / \mathrm{U}^{235} \mathrm{~F}$ is sion

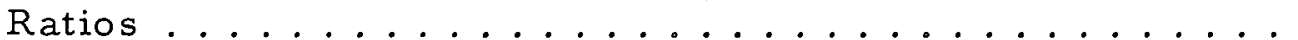

V. Calculated and Experimental $\mathrm{U}^{236} / \mathrm{U}^{235}$ and $\mathrm{U}^{238} / \mathrm{U}^{235} \mathrm{Fission}$

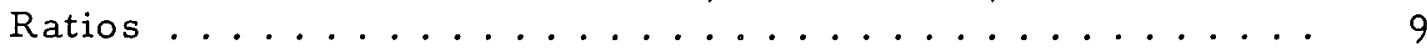

VI. Calculated and Experimental $\mathrm{Th}^{232} / \mathrm{U}^{235} \mathrm{Fission}$ Ratios .... 9

VII. Comparison of ZPR-III and AETR Fission Ratios. ...... 10

VIII. Reactivity Effects of $\mathrm{U}^{235} \ldots \ldots \ldots \ldots \ldots$

IX. Reactivity Effects for $\mathrm{Pu}^{239}$ and $\mathrm{U}^{233} \ldots \ldots \ldots$

X. Reactivity Effects of $\mathrm{Th}^{232}$ and $\mathrm{U}^{238} \ldots \ldots \ldots \ldots$

XI. Reactivity Effects of $\mathrm{B}^{10}$ and $\mathrm{Ta} \ldots \ldots \ldots$

XII. Reactivity Effects for Steel, $\mathrm{Zr}, \mathrm{Mo}$, and $\mathrm{Nb} \ldots \ldots 16$

XIII. Reactivity Effects of Carbon, Sodium, and Aluminum .... 17

XIV. Summary of Reactivity Data............... 18

XV. Calculated and Measured Importances ............. 20 


\title{
AN ANALYSIS OF \\ SIX AETR FAST CRITICAL EXPERIMENTS
}

by

William G. Davey

\begin{abstract}
Atomics International has constructed a series of multiregion fast-thermal critical assemblies as part of the Advanced Epithermal Thorium Reactor (AETR) program to obtain data on the physics of $\mathrm{U}^{233}-\mathrm{Th}$-fueled reactors. In each case, the central test region was of a composition appropriate to a full-scale core. The physics data obtained in six cores, where the test regions simulated the cores of fairly large fast reactors, have been analyzedusing a crosssection set previously used in an analysis of ZPR-III fast critical assemblies. These data are central fission ratios, relative reactivities of certain materials, and the relative importance of neutron sources of different energies. Trends are identified in the differences between calculated and measured data, and these are compared with similar trends found in the ZPR-III as semblies.
\end{abstract}

\section{INTRODUCTION}

The Advanced Epithermal Thorium Reactor (AETR) critical assembly has been used by Atomics International to make physics measurements to aid in the design of a power reactor based on the $U^{233}$-thorium fuel cycle. Since the available supply of $\mathrm{U}^{233}$ was less than that required for a full-scale critical assembly, a multiregion assembly was used. The machine was of splithalves design, and a critical assembly was built by loading plates of material into aluminum drawers and inserting these into two arrays of 2 -in.-square aluminum tubes, which were clamped on one movable, and one stationary, table.

The assemblies were pseudospheres, typically containing five regions:

(a) The central test region, which was of the composition of a fullscale reactor; this was made as large as permitted by the available amount of $\mathrm{U}^{233}$. 
(b) A buffer region, which surrounded the test region; this was of similar composition to the test region, except for the substitution of $U^{235}$ for the $\mathrm{U}^{233}$; the spectra in the buffer and test regions matched as closely as possible.

(c) A decoupler of thorium, which surrounded the buffer region; this absorbed thermal neutrons from the driver region, preventing their leakage to the inner high-energy regions.

place.

(d). A U $U^{235}$-polyethylene driver, in which $90 \%$ of the fissions took

(e) An outer polyethylene reflector.

On occasion, the buffer region was omitted, and in some cases the test region was fueled with $U^{235}$ rather than $U^{233}$.

The facility and experiments have been described fully by Atomics International staff, $(1,2)$ and all experimental data discussed here have been taken from these two references.

In six AETR assemblies, the test regions corresponded to the cores of dilute fast reactors. It is of interest to study these by using the same methods and nuclear data previously used for an analysis of 23 ZPR-III fast critical as semblies [Davey $(3-6)]$.

Hence, calculated and measured values of fission ratios, relative reactivity worths, and source importances have been compared, and trends in the differences between calculation and experiment have been identified and discussed.

In addition, the trends found with the AETR fission ratios and reactivity measurements have been compared with those found in the $U^{235}$-fueled ZPR-III systems. It is not obvious that the AETR and ZPR-III trends may be compared, but the general similarity in the cross sections of $U^{233}$ and $U^{235}$ in the fast-energy region indicates that the spectra in $\mathrm{U}^{233}$ - and $\mathrm{U}^{235}$-fueled reactors of comparable sizes are not greatly different. Also, to anticipate some of the results of the analysis, the trends found with the $\mathrm{U}^{235}$-fueled AETR Assemblies 1 and 3 are similar to those found in the $U^{233}$-fueled Assemblies $2,5,8$, and 9 , and this gives some support for the validity of the comparison.

The ZPR-III analysis included critical sizes, but this was not considered here since the critical sizes of the AETR assemblies were largely determined by the thermalized driver region and hence were insensitive to the test-region composition. 
AETR Assemblies 1, 2, 3, 5, 8, and 9 had test regions with hard spectra. Of these, Assemblies 1 and 3 had $U^{235}$-fueled test regions, and the remaining four assemblies had $\mathrm{U}^{233}$ - and thorium-containing test regions. The compositions and dimensions of these systems are listed in Table I. The Assembly 1 test region was similar in composition to the core of ZPR-III Assembly 2A.

Table I

COMPOSITIONS AND DIMENSIONS OF AETR TEST REGIONS

\begin{tabular}{|c|c|c|c|c|c|c|c|c|c|c|}
\hline \multirow{2}{*}{$\begin{array}{l}\text { Assembly } \\
\text { Number }\end{array}$} & \multicolumn{8}{|c|}{ Composition of Test Region (atoms $/ \mathrm{cm}^{3} \times 10^{-22}$ ) } & \multirow{2}{*}{$\begin{array}{c}\text { Outer } \\
\text { Radius of } \\
\text { Test Region } \\
(\mathrm{cm})\end{array}$} & \multirow{2}{*}{$\begin{array}{l}\text { Outer } \\
\text { Radius of } \\
\text { Buffer } \\
\text { (cm) }\end{array}$} \\
\hline & $\mathrm{U}^{233}$ & $\mathrm{U}^{235}$ & $\mathrm{U}^{238}$ & Th & Steel & Al & 0 & C & & \\
\hline 1 & - & 0.661 & 0.049 & - & 1.892 & 1.873 & - & - & 14.02 & 19.10 \\
\hline 2 & 0.0907 & - & - & 0.815 & 1.321 & 1.388 & 0.249 & 0.996 & 18.85 & (a) \\
\hline 3 & - & 0.203 & 0.015 & 0.815 & 1.371 & 1.639 & - & 0.996 & 18.85 & (a) \\
\hline 5 & 0.0853 & - & - & 0.601 & 1.254 & 1.162 & 0.234 & 2.116 & 24.26 & 29.67 \\
\hline 8 & 0.0907 & - & - & 0.819 & 1.376 & 1.385 & 0.249 & 1.012 & 25.53 & 30.63 \\
\hline 9 & 0.0907 & - & - & 0.819 & 1.376 & 1.729 & 0.249 & - & 25.53 & 30.63 \\
\hline
\end{tabular}

(a) There was no buffer region in this core.

\section{THE CROSS-SECTION SET}

The cross-section set used for this study was that of Yiftah, Okrent, and Moldauer(7) with some modifications in the $\mathrm{U}^{233}, \mathrm{U}^{235}, \mathrm{Pu}^{239}$, steel, and aluminum data. Its derivation has been fully described by Davey $(3,4)$ and will not be discussed here.

\section{CALCULATION OF THE TEST REGION SPECTRA}

This calculation presented a considerable problem since the crosssection set was terminated at a lower energy limit of $500 \mathrm{eV}$. Hence, although it could be used to describe the fast spectra in the test and buffer regions, it was inadequate to describe the thermal and epithermal spectra in the driver and reflector, and a straightforward calculation of the spectrum throughout the whole assembly was not possible. However, the AETR assemblies were designed with the objective of making the real and adjoint spectra in the test region identical with those of the full-scale reactor having the same composition [Campise(8)], and here we have assumed that this objective was realized. Thus, as the AETR test regions generally simulate fairly large, fast reactors, and since fundamental mode calculations give accurate central spectra for such systems, this computational method has been used in the present study. 
The validity of fundamental mode calculations was examined by comparing data obtained with spectra computcd using this method, and with spectra calculated using transport theory (DSN) with spherical models of a range of $Z P R$-III assemblies. The fission ratios and relative reactivities were in good agreement except for small systems, and it was concluded that five of the six AETR assemblies considered here corresponded to sufficiently large reactors to justify the use of the fundamental mode technique. The exception was AETR Assembly 1, where it is believed that the computed spectra are significantly different from those that would be obtained by using more refined methods.

We would therefore, emphasize that the calculated data for Assembly 1 must be treated with reserve. These uncertainties in the computed spectra may be responsible for some apparent deviations of the Assembly 1 data from those of the other assemblies (e.g., in fission ratios), but it does not appear that the general conclusions of this study are affected.

The calculations were made using an IBM-1620 computer program, which gave both real and adjoint spectra. These spectra were then used for the calculation of the fission ratios, reactivity effects, and source importances.

The spectra calculated using the test-region compositions of Table I are given in Table II.

Table II

CALCULATED(a) REAL AND ADJOINT SPECTRA

\begin{tabular}{|c|c|c|c|c|c|c|c|c|c|c|c|c|c|}
\hline \multirow{2}{*}{ Group } & \multirow{2}{*}{$\begin{array}{l}\text { Lower- } \\
\text { energy } \\
\text { Limit } \\
\text { (keV) }\end{array}$} & \multicolumn{2}{|c|}{ Assembly 1} & \multicolumn{2}{|c|}{ Assembly 9} & \multicolumn{2}{|c|}{ Assembly 3} & \multicolumn{2}{|c|}{ Assembly 8} & \multicolumn{2}{|c|}{ Assembly 2} & \multicolumn{2}{|c|}{ Assembly 5} \\
\hline & & Real & Adjoint & Real & Adjoint & Real & Adjoint & Real & Adjoint & Real & Adjoint & Real & Adjoint \\
\hline 1 & 3668 & 0.039 & 0.049 & 0.013 & 0.067 & 0.016 & 0.064 & 0.014 & 0.066 & 0.014 & 0.066 & 0.015 & 0.062 \\
\hline 2 & 2225 & 0.078 & 0.050 & 0.026 & 0.066 & 0.033 & 0.064 & 0.028 & 0.066 & 0.028 & 0.066 & 0.031 & 0.062 \\
\hline 3 & 1350 & 0.125 & 0.051 & 0.046 & 0.065 & 0.055 & 0.063 & 0.048 & 0.064 & 0.048 & 0.064 & 0.054 & 0.061 \\
\hline 4 & 825 & 0.155 & 0.050 & 0.098 & 0.063 & 0.102 & 0.060 & 0.091 & 0.063 & 0.092 & 0.063 & 0.087 & 0.061 \\
\hline 5 & 500 & 0.181 & 0.052 & 0.145 & 0.063 & 0.141 & 0.060 & 0.127 & 0.063 & 0.127 & 0.062 & 0.110 & 0.061 \\
\hline 6 & 300 & 0.160 & 0.055 & 0.162 & 0.062 & 0.153 & 0.061 & 0.135 & 0.062 & 0.135 & 0.062 & 0.112 & 0.062 \\
\hline 7 & 180 & 0.112 & 0.058 & 0.146 & 0.061 & 0.133 & 0.061 & 0.126 & 0.062 & 0.126 & 0.062 & 0.106 & 0.062 \\
\hline 8 & 110 & 0.071 & 0.062 & 0.108 & 0.060 & 0.104 & 0.061 & 0.102 & 0.061 & 0.102 & 0.061 & 0.090 & 0.063 \\
\hline 9 & 67 & 0.048 & 0.064 & 0.085 & 0.060 & 0.085 & 0.061 & 0.087 & 0.061 & 0.087 & 0.061 & 0.082 & 0.063 \\
\hline 10 & 40.7 & 0.022 & 0.065 & 0.083 & 0.061 & 0.075 & 0.062 & 0.083 & 0.062 & 0.083 & 0.062 & 0.079 & 0.064 \\
\hline 11 & 25 & 0.006 & 0.067 & 0.038 & 0.062 & 0.042 & 0.063 & 0.052 & 0.063 & 0.052 & 0.063 & 0.058 & 0.065 \\
\hline 12 & 15 & 0.002 & 0.068 & 0.034 & 0.064 & 0.034 & 0.064 & 0.048 & 0.065 & 0.048 & 0.065 & 0.056 & 0.066 \\
\hline 13 & 9.1 & 0.001 & 0.075 & 0.009 & 0.067 & 0.014 & 0.066 & 0.025 & 0.065 & 0.025 & 0.065 & 0.038 & 0.066 \\
\hline 14 & 5.5 & 0.000 & 0.076 & 0.004 & 0.064 & 0.007 & 0.065 & 0.015 & 0.064 & 0.014 & 0.064 & 0.026 & 0.065 \\
\hline 15 & 2.1 & 0.000 & 0.078 & 0.003 & 0.066 & 0.005 & 0.065 & 0.015 & 0.064 & 0.015 & 0.064 & 0.037 & 0.064 \\
\hline 16 & 0.5 & 0.000 & 0.080 & 0.000 & 0.049 & 0.001 & 0.060 & 0.004 & 0.049 & 0.004 & 0.050 & 0.019 & 0.053 \\
\hline
\end{tabular}

(a) Fundamental mode calculations.

\section{ANALYSIS OF FISSION RATIOS}

Fission ratios of $\mathrm{Th}^{232}, \mathrm{U}^{233}, \mathrm{U}^{234}, \mathrm{U}^{236}, \mathrm{U}^{238}, \mathrm{~Np}^{237}$, and $\mathrm{Pu}^{239} \mathrm{rela}-$ tive to $U^{235}$ have been measured in the AETR assemblies. Five of these have also been measured in $\mathrm{ZPR}$-III systems and provide a good basis for comparison of techniques. 
The accuracy of the ZPR-III chamber intercalibrations has recently been re-examined by Davey and Amundson,(9) and it would seem appropriate to describe the AETR techniques briefly and consider the accuracy of the measurements.

An AETR counter was made by placing an electroplated foil of fissile material in a cavity in an aluminum cap and placing a solid-state detector on top of this foil. Most of the counters were then calibrated by using the solidstate detector to count the alpha activities of the foils. Knowledge of the isotopic content of the foils and the specific alpha activities of each isotope gave the effective masses of materials in the counters.

When counting in the reactor, the fraction of fission pulses counted in each chamber must be the same. However, in cases of high alpha activity [e.g., $\mathrm{U}^{233}$, Figure V-4, AI-7614(1)], the alpha and fission pulse distributions overlap considerably and selection of satisfactory operating conditions may present some difficulty.

A second method of calibration provided a check on some of the se alpha calibrations. Since the $\mathrm{U}^{234}, \mathrm{U}^{235}, \mathrm{U}^{236}$, and natural uranium counters had appreciable known isotopic fractions of $U^{235}$, a comparison of their count rates in a thermal neutron flux provided a good measure of the fissile contents.

In Assembly 3, the $\mathrm{U}^{234} / \mathrm{U}^{235}, \mathrm{U}^{236} / \mathrm{U}^{235}$, and $\mathrm{U}^{238} / \mathrm{U}^{235}$ fission ratios given by the two calibration methods differed by $1 / 2,7$, and $5 \%$, respectively $[$ Table $\mathrm{V}-2, \mathrm{AI}-7614(1)]$. Also, the $\mathrm{U}^{238} / \mathrm{U}^{235}$ ratios obtained, using natural and a depleted uranium counter, differed by $2 \frac{1}{2} \%$. The accuracy of these comparisons may be interpreted as some indication of the experimental uncertainties.

The calculated and measured ratios are compared in Tables III through VI. In general, the agreement is not good.

Table III

CALCULATED AND EXPERIMENTAL PU ${ }^{239} / \mathrm{U}^{235}$ AND U $233 / \mathrm{U}^{235}$ FISSION RATIOS

\begin{tabular}{|c|c|c|c|c|c|c|c|}
\hline \multirow{3}{*}{$\begin{array}{l}\text { Assembly } \\
\text { Number }\end{array}$} & \multirow{3}{*}{$\begin{array}{c}\text { Median } \\
\text { Fission } \\
\text { Energy. } \\
(\mathrm{keV})\end{array}$} & \multicolumn{3}{|c|}{$\mathrm{Pu} 239 / \mathrm{u}^{235}$} & \multicolumn{3}{|c|}{$u^{233} / u^{235}$} \\
\hline & & \multicolumn{3}{|c|}{ Weighted Mean $C / E=1.03$} & \multicolumn{3}{|c|}{ Weighted Mean $C / E=1.07$} \\
\hline & & $\begin{array}{l}\text { Calculated } \\
\text { Ratio, } \\
\text { C }\end{array}$ & $\begin{array}{c}\text { Experimental } \\
\text { Ratio, } \\
\text { E }\end{array}$ & Ratio, C/E & $\begin{array}{c}\text { Calculated } \\
\text { Ratio, } \\
\text { C }\end{array}$ & $\begin{array}{c}\text { Experimental } \\
\text { Ratio, } \\
\text { E }\end{array}$ & Ratio, C/E \\
\hline $\begin{array}{l}1 \\
9 \\
3 \\
8 \\
2 \\
5\end{array}$ & $\begin{array}{r}422 \\
190 \\
140 \\
127 \\
127 \\
63\end{array}$ & $\begin{array}{l}1.308 \\
1.136 \\
1.127 \\
1.061 \\
1.063 \\
0.988\end{array}$ & $\begin{array}{c}- \\
1.09 \pm 0.05 \\
1.44 \pm 0.06(\mathrm{a}) \\
- \\
- \\
0.96 \pm 0.03\end{array}$ & $\begin{array}{c}- \\
1.04 \pm 0.05 \\
0.78 \pm 0.03(a) \\
- \\
- \\
1.03 \pm 0.03\end{array}$ & $\begin{array}{l}1.565 \\
1.549 \\
1.541 \\
1.519 \\
1.519 \\
1.477\end{array}$ & $\begin{array}{ll} & - \\
1.37 & \pm 0.04 \\
2.02 & \pm 0.40 \\
1.44 & \pm 0.04 \\
1.70 & \pm 0.20 \\
1.392 & \pm 0.028\end{array}$ & $\begin{array}{c}- \\
1.13 \pm 0.03 \\
0.76 \pm 0.15 \\
1.05 \pm 0.03 \\
0.89 \pm 0.10 \\
1.06 \pm 0.02\end{array}$ \\
\hline
\end{tabular}

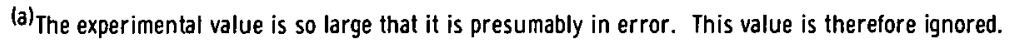


Table I

CALCULATED AND EXPERIMENTAL U234/U235 AND Np $237 / \mathrm{U}^{235}$ FISSION RATIOS

\begin{tabular}{|c|c|c|c|c|c|c|c|}
\hline \multirow{3}{*}{$\begin{array}{l}\text { Assembly } \\
\text { Number }\end{array}$} & \multirow{3}{*}{$\begin{array}{c}\text { Median } \\
\text { Fission } \\
\text { Energy, } \\
(\text { keV) }\end{array}$} & \multicolumn{3}{|c|}{$u^{234} / \mathrm{U}^{235}$} & \multicolumn{3}{|c|}{$\mathrm{Np}^{237} / \mathrm{U}^{235}$} \\
\hline & & \multicolumn{3}{|c|}{ Weighted Mean $C / E=1.14$} & \multicolumn{3}{|c|}{ Weighted Mean $C / E=1.08$} \\
\hline & & $\begin{array}{l}\text { Calculated } \\
\text { Ratio, } \\
\text { C }\end{array}$ & $\begin{array}{c}\text { Experimental } \\
\text { Ratio, } \\
\text { E }\end{array}$ & Ratio, C/E & $\begin{array}{l}\text { Calculated } \\
\text { Ratio, } \\
\text { C }\end{array}$ & $\begin{array}{c}\text { Experimental } \\
\text { Ratio. } \\
\text { E }\end{array}$ & Ratio, C/E \\
\hline $\begin{array}{l}1 \\
9 \\
3 \\
8 \\
2 \\
5\end{array}$ & $\begin{array}{r}422 \\
190 \\
140 \\
127 \\
127 \\
63\end{array}$ & $\begin{array}{l}0.536 \\
0.259 \\
0.271 \\
0.218 \\
0.220 \\
0.185\end{array}$ & $\begin{array}{l}0.52 \pm 0.05 \\
0.234 \pm 0.005 \\
0.228 \pm 0.003 \\
0.191 \pm 0.003 \\
0.194 \pm 0.010 \\
0.175 \pm 0.007\end{array}$ & $\begin{array}{l}1.03 \pm 0.10 \\
1.11 \pm 0.02 \\
1.19 \pm 0.02 \\
1.14 \pm 0.02 \\
1.13 \pm 0.06 \\
1.06 \pm 0.04\end{array}$ & $\begin{array}{l}0.531 \\
0.247 \\
0.260 \\
0.209 \\
0.211 \\
0.179\end{array}$ & $\begin{array}{l}0.432 \pm 0.040 \\
0.236 \pm 0.004 \\
0.233 \pm 0.005 \\
0.196 \pm 0.004 \\
0.190 \pm 0.020 \\
0.169 \pm 0.003\end{array}$ & $\begin{array}{l}1.23 \pm 0.11 \\
1.05 \pm 0.02 \\
1.12 \pm 0.02 \\
1.07 \pm 0.02 \\
1.11 \pm 0.10 \\
1.06 \pm 0.02\end{array}$ \\
\hline
\end{tabular}

Table I

CALCULATED AND EXPERIMENTAL U $236 / \mathrm{U}^{235}$ AND U $238 / \mathrm{U}^{235} \mathrm{FISSION} \mathrm{RATIOS}$

\begin{tabular}{|c|c|c|c|c|c|c|c|}
\hline \multirow{3}{*}{$\begin{array}{l}\text { Assembly } \\
\text { Number }\end{array}$} & \multirow{3}{*}{$\begin{array}{c}\text { Median } \\
\text { Fission } \\
\text { Energy, } \\
(\mathrm{keV})\end{array}$} & \multicolumn{3}{|c|}{ U236/U235 } & \multicolumn{3}{|c|}{$u^{238} / u^{235}$} \\
\hline & & \multicolumn{3}{|c|}{ Weighted Mean $C / E=1.13$} & \multicolumn{3}{|c|}{ Weighted Mean $C / E=1.04$} \\
\hline & & $\begin{array}{l}\text { Calculated } \\
\text { Ratio, } \\
\text { C }\end{array}$ & $\begin{array}{c}\text { Experimental } \\
\text { Ratio, } \\
\text { E }\end{array}$ & Ratio, C/E & $\begin{array}{l}\text { Calculated } \\
\text { Ratio, } \\
\text { C }\end{array}$ & $\begin{array}{c}\text { Experimental } \\
\text { Ratio. } \\
\text { E }\end{array}$ & Ratio, C/E \\
\hline $\begin{array}{l}1 \\
9 \\
3 \\
8 \\
2 \\
5\end{array}$ & $\begin{array}{r}422 \\
190 \\
140 \\
127 \\
127 \\
63\end{array}$ & $\begin{array}{l}0.197 \\
0.0725 \\
0.0818 \\
0.0648 \\
0.0656 \\
0.0599\end{array}$ & $\begin{array}{l}0.153 \pm 0.015 \\
0.063 \pm 0.003 \\
0.0705 \pm 0.003 \\
0.0585 \pm 0.0017 \\
0.0545 \pm 0.0027 \\
0.0545 \pm 0.0017\end{array}$ & $\begin{array}{l}1.29 \pm 0.13 \\
1.15 \pm 0.05 \\
1.16 \pm 0.05 \\
1.11 \pm 0.03 \\
1.20 \pm 0.06 \\
1.10 \pm 0.03\end{array}$ & $\begin{array}{l}0.0924 \\
0.0285 \\
0.0339 \\
0.0265 \\
0.0269 \\
0.0258\end{array}$ & $\begin{array}{l}0.076 \pm 0.007 \\
0.0284 \pm 0.0006 \\
0.0306 \pm 0.0005 \\
0.0281 \pm 0.0010 \\
0.0248 \pm 0.0013 \\
0.0240 \pm 0.0006\end{array}$ & $\begin{array}{l}1.22 \pm 0.12 \\
1.00 \pm 0.02 \\
1.11 \pm 0.02 \\
0.94 \pm 0.03 \\
1.08 \pm 0.06 \\
1.08 \pm 0.03\end{array}$ \\
\hline
\end{tabular}

Table VI

CALCULATED AND EXPERIMENTAL $\mathrm{Th}^{232} / \mathrm{U}^{235}$ FISSION RATIOS

\begin{tabular}{|c|c|c|c|c|}
\hline $\begin{array}{c}\text { Assembly } \\
\text { Number }\end{array}$ & $\begin{array}{c}\text { Median } \\
\text { Fission } \\
\text { Energy, } \\
(\mathrm{keV})\end{array}$ & $\begin{array}{c}\text { Calculated } \\
\text { Ratio, } \\
\mathrm{C}\end{array}$ & $\begin{array}{c}\text { Experimental } \\
\text { Ratio, } \\
\mathrm{E}\end{array}$ & Ratio, C/E \\
\hline 1 & 422 & 0.0191 & $0.015 \pm 0.002$ & $1.27 \pm 0.17$ \\
9 & 190 & 0.00569 & $0.0066 \pm 0.0002$ & $0.86 \pm 0.03$ \\
3 & 140 & 0.00689 & $0.0069 \pm 0.0002$ & $1.00 \pm 0.03$ \\
8 & 127 & 0.00533 & $0.0064 \pm 0.0002$ & $0.83 \pm 0.03$ \\
2 & 127 & 0.00540 & $0.0061 \pm 0.0006$ & $0.89 \pm 0.09$ \\
5 & 63 & 0.00525 & $0.00504 \pm 0.0003$ & $1.04 \pm 0.06$ \\
\hline
\end{tabular}

Weighted mean value of $C / E=0.91$.

ZPR-III experience ${ }^{(5)}$ has indicated that for any given fission ratio, the ratio of calculated and measured values is not very dependent upon the neutron spectrum. Hence, for each fission ratio, a mean value of the ratio of calculated and measured values $(C / E)$ may be derived. The evidence of the AETR data does not contradict this experience, and hence weighted 
mean values of $C / E$ have been obtained. These are compared in Table VII with the mean $C / E$ values obtained from the ZPR-III data. The ZPR-III values are those recently derived by Davey and Amundson(9) after a reevaluation of ZPR-III fission chamber calibrations and differ in some respects from previous data. (5)

Table VII

COMPARISON OF ZPR-III AND AETR FISSION RATIOS

\begin{tabular}{|c|c|c|}
\hline \multirow{2}{*}{$\begin{array}{c}\text { Fission } \\
\text { Ratio }\end{array}$} & \multicolumn{2}{|c|}{$\begin{array}{c}\text { Mean Ratio of Calculated and } \\
\text { Experimental Values, C/E }\end{array}$} \\
\cline { 2 - 3 } & From AETR & From ZPR-III(a) \\
\hline $\mathrm{Pu}^{239} / \mathrm{U}^{235}$ & 1.03 & 1.05 \\
$\mathrm{U}^{233} / \mathrm{U}^{235}$ & 1.07 & 1.04 \\
$\mathrm{U}^{234} / \mathrm{U}^{235}$ & 1.14 & 1.02 \\
$\mathrm{Pu}$ & $(\mathrm{b})$ & 1.05 \\
$\mathrm{~Np}^{237} / \mathrm{U}^{235}$ & 1.08 & $(\mathrm{~b})$ \\
$\mathrm{U}^{236} / \mathrm{U}^{235}$ & 1.13 & 1.07 \\
$\mathrm{U}^{238} / \mathrm{U}^{235}$ & 1.04 & 1.08 \\
$\mathrm{Th}^{232} / \mathrm{U}^{235}$ & 0.91 & $(\mathrm{~b})$ \\
\hline
\end{tabular}

(a) These are the values recommended by Davey and Amundson. (9) They are based on revised experimental data for the ZPR-III assemblies and differ to some extent from previously published data.

(b) Not measured.

Table VII shows that there is some measure of agreement between the AETR and ZPR-III results. The disagreement for the $\mathrm{Pu}^{239} / \mathrm{U}^{235}, \mathrm{U}^{233} /$ $\mathrm{U}^{235}$, and $\mathrm{U}^{238} / \mathrm{U}^{235}$ ratios is no more than $4 \%$, and those for the $\mathrm{U}^{236} / \mathrm{U}^{235}$ and $\mathrm{U}^{234} / \mathrm{U}^{235}$ are, respectively, 6 and $12 \%$. In all cases except for the AETR $\mathrm{Th}^{232} / \mathrm{U}^{235}$ ratio, the calculated ratios exceed the experimental values. Davey and Amundson(9) established independent calibrations of the ZPR-III chambers, which agreed, in general, to within a few percent with the original calibrations. It is believed that the ZPR-III ratios are generally established to about 2 to $3 \%$ accuracy, with the exception of $\mathrm{Pu}^{240}$, where the uncertainty may be $5 \%$. Hence, the 6 and $12 \%$ differences for $U^{236} / U^{235}$ and $U^{234} / U^{235}$ may arise from the uncertainties in the AETR measurements. The differences of $4 \%$ or less are probably within experimental error. 
In general, the AETR fission ratios appear to indicate that the calculated spectra are too hard, as only the $\mathrm{Th}^{232} / \mathrm{U}^{235}$ ratio gives a $\mathrm{C} / \mathrm{E}$ value less than unity.

The fact that the average value of $\mathrm{C} / \mathrm{E}$ for the $\mathrm{Th}^{232} / \mathrm{U}^{235}$ ratio is less than unity may indicate that the $\mathrm{Th}^{232}$ fission cross section used in the calculations is too low.

\section{ANALYSIS OF REACTIVITY DATA}

The relative reactivity effects of 14 materials, which have been substituted in both the AETR test regions and ZPR-III cores, have been analyzed using perturbation theory. The present analysis closely follows that used for the ZPR-III data, so the two sets of data may be compared. The perturbation calculations were made using an IBM-1620 program (10) and unperturbed real and adjoint fluxes obtained from the fundamental mode calculations. The perturbation matrix for each material is given by Davey $(6)$ and was constructed using the modified Yiftah-Okrent-Moldauer(7) cross-section set used for the fundamental mode calculations.

The reactivity data have several important features:

First, since the perturbation matrices used in the calculations are constructed only for one material, the reactivity effects of any other materials in the experimental samples must be subtracted. It was assumed that reactivity effects of different materials were additive and that the experimental reactivities for the diluents (largely oxygen, aluminum, and steel) were used to make corrections. This correction procedure inevitably introduces additional errors and, in addition, the fundamental assumption that reactivity effects of different materials are additive when they are mixed may not be correct. This question is discussed more fully when the detailed results are considered.

Second, perturbation theory calculations may be legitimately compared with experiments, only when the experimental samples introduce negligible flux and spectrum perturbations. This criterion is not met with many of the AETR samples, and in these cases, the reactivity effects that would be obtained with very small samples have been deduced. The necessary corrections are discussed in detail when the individual reactivity measurements are considered.

Thirdly, a private communication from S. G. Carpenter of Atomics International disclosed that the true experimental errors on the reactivity measurements are one-tenth those quoted in references (1) and (2). 
In all cases, the reactivity effects are expressed as millibarns per atom, and the experimental data have been normalized to the calculated reactivity effects for $\mathrm{U}^{235}$.

In all the tables of reactivity data, the identifications are those given by. Atomics International. The masses quoted are those of the principal materials for which the calculations were performed.

$\underline{\mathrm{U}^{235}}$

The $U^{235}$ data are presented in Table VIII. The reactivity effects of all diluents and the sample holder have been substracted.

Table VIII

REACTIVITY EFFECTS OF U235

\begin{tabular}{|c|c|c|c|c|c|c|c|c|c|}
\hline \multirow{2}{*}{$\begin{array}{c}\text { Assembly } \\
\text { Number } \\
\left(\begin{array}{c}\text { Median } \\
\text { Fission } \\
\text { Energy, keV }\end{array}\right)\end{array}$} & \multicolumn{7}{|c|}{ Experimental Reactivity (cents/g-mole) versus Sample Size (a) } & \multirow[b]{2}{*}{$\begin{array}{l}\text { Calculated } \\
\text { Reactivity } \\
\text { (mb) }\end{array}$} & \multirow{2}{*}{$\begin{array}{l}\text { Normalization } \\
\text { Factor for } \\
\text { Experimental } \\
\text { Data (b) }\end{array}$} \\
\hline & $\begin{array}{l}98-U \\
\text { (Metal) } \\
110.09 \mathrm{~g}\end{array}$ & $\begin{array}{l}37-U \\
\text { (Metal) } \\
41.73 \mathrm{~g}\end{array}$ & $\begin{array}{l}U^{235}-2 \\
\text { (0xide) } \\
15.22 \mathrm{~g}\end{array}$ & $\begin{array}{l}8-\mathrm{U} \\
\text { (Metal) } \\
9.02 \mathrm{~g}\end{array}$ & $\begin{array}{l}\mathrm{U}^{235}-3 \\
\text { (0xide) } \\
8.40 \mathrm{~g}\end{array}$ & $\begin{array}{c}1-\mathrm{U} \\
\text { (Metal) } \\
1.12 \mathrm{~g}\end{array}$ & $\begin{array}{c}\text { Estimated } \\
\text { Reactivity for } \\
\text { Zero-size Metallic } \\
\text { Sample (c) }\end{array}$ & & \\
\hline$\underset{(422)}{1}$ & $\begin{array}{r}6.65 \\
\pm 0.07\end{array}$ & $\begin{array}{r}6.07 \\
\pm 0.07\end{array}$ & - & $\begin{array}{r}5.74 \\
\pm 0.06\end{array}$ & - & $\begin{array}{r}5.0 \\
\pm 0.2\end{array}$ & $\begin{array}{r}6.25 \\
\pm 0.07\end{array}$ & 1729 & 277 \\
\hline $\begin{array}{c}3 \\
(140)\end{array}$ & $\begin{array}{r}1.49 \\
\pm 0.02\end{array}$ & $\begin{array}{r}1.30 \\
\pm 0.02\end{array}$ & $\begin{array}{r}1.16 \\
\pm 0.02\end{array}$ & $\begin{array}{c}1.5 \\
\pm 0.05\end{array}$ & - & - & $\begin{array}{r}1.40 \\
\pm 0.02\end{array}$ & 2033 & 1452 \\
\hline $\begin{array}{c}2 \\
(127)\end{array}$ & $\begin{array}{r}1.51 \\
+0.02\end{array}$ & $\begin{array}{r}1.36 \\
\pm 0.02\end{array}$ & $\begin{array}{r}1.21 \\
\pm 0.02\end{array}$ & $\begin{array}{r}1.08 \\
\pm 0.03\end{array}$ & $\begin{array}{r}0.95 \\
\pm 0.03\end{array}$ & $\begin{array}{r}1.2 \\
\pm 0.2\end{array}$ & $\begin{array}{r}1.42 \\
\pm 0.02\end{array}$ & 2221 & 1564 \\
\hline $\begin{array}{c}8 \\
(127)\end{array}$ & $\begin{array}{r}2.40 \\
\pm 0.02\end{array}$ & $\begin{array}{r}2.27 \\
\pm 0.02\end{array}$ & $\begin{array}{r}1.98 \\
\pm 0.02\end{array}$ & $\begin{array}{r}1.97 \\
\pm 0.03\end{array}$ & $\begin{array}{r}1.52 \\
\pm 0.03\end{array}$ & - & $\begin{array}{r}2.26 \\
\pm 0.02\end{array}$ & 2234 & 988 \\
\hline $\begin{array}{c}5 \\
(67)\end{array}$ & $\begin{array}{r}2.35 \\
\pm 0.02\end{array}$ & $\begin{array}{r}2.22 \\
\pm 0.02\end{array}$ & $\begin{array}{r}2.13 \\
\pm 0.02\end{array}$ & $\begin{array}{r}1.93 \\
\pm 0.02\end{array}$ & $\begin{array}{r}1.75 \\
\pm 0.02\end{array}$ & $\begin{array}{r}2.4 \\
+0.2\end{array}$ & $\begin{array}{r}2.21 \\
\pm 0.02\end{array}$ & 2287 & 1035 \\
\hline
\end{tabular}

(a) The uncertainties are based on the quoted errors only. The true uncertainties may well be larger.

(b)(Calculated reactivity)/(zero-sample-size experimental reactivity).

(c) $98-U$ data $\times 0.94$ (see text).

Six different samples were used, and the experimental data clearly indicate a decrease in the reactivity per $\mathrm{U}^{235}$ atom as the amount of $\mathrm{U}^{235}$ decreases. This effect is well known in fast reactors and arises because the spectrum inside a $\mathrm{U}^{235}$ sample of finite size is harder than the reactor spectrum and the $U^{235}$ reactivity is greater in this harder spectrum. The effect has been observed experimentally in metallic samples in the Argonne reactors ZPR-III and ZPR-VI(11) and the British reactor ZEBRA. (12) However, the AETR data show much greater apparent sample-size effects than have been observed with metallic samples in the other reactors, and it appears possible that part of the effects observed in AETR arises from other causes; for example, the simple subtraction of the effects of diluents may not be valid.

Since the perturbation calculations were made for pure $U^{235}$ and the 98-U sample is the closest to this, the 98-U data have corrected to zero sample size on the basis of the ZPR-III, ZPR-VI, and ZEBRA experimental 
data. These latter data indicate that the reactivity per atom of a small $\mathrm{U}^{235}$ sample would be $6 \%$ less reactive than that given by the $98-\mathrm{U}$ measurements.

The normalization factor in the last column of Table VIII is the amount by which the experimental reaclivity of other materials must be multiplied to give their reactivity in millibarns per atom.

$\underline{\mathrm{Pu}^{239} \text { and } \mathrm{U}^{233}}$

The reactivity data for $\mathrm{Pu}^{239}$ and $\mathrm{U}^{233}$ are presented in Table IX. The sample holder and diluent reactivity effects have been subtracted from the experimental data. Apparent sample-size effects are shown with the $\mathrm{Pu}^{239}$ in all reactors where it was measured. With $\mathrm{U}^{233}$, such effects are shown in some reactors and not in others. All the $\mathrm{Pu}^{239}$ and $\mathrm{U}^{233}$ samples were nominally oxide and contained appreciable quantities of diluents, whereas the calculations were for the pure isotopes, so that we have the same difficulties of interpretation that were apparent with the $U^{235}$.

Table IX.

REACTIVITY EFFECTS FOR PU 239 AND U 233

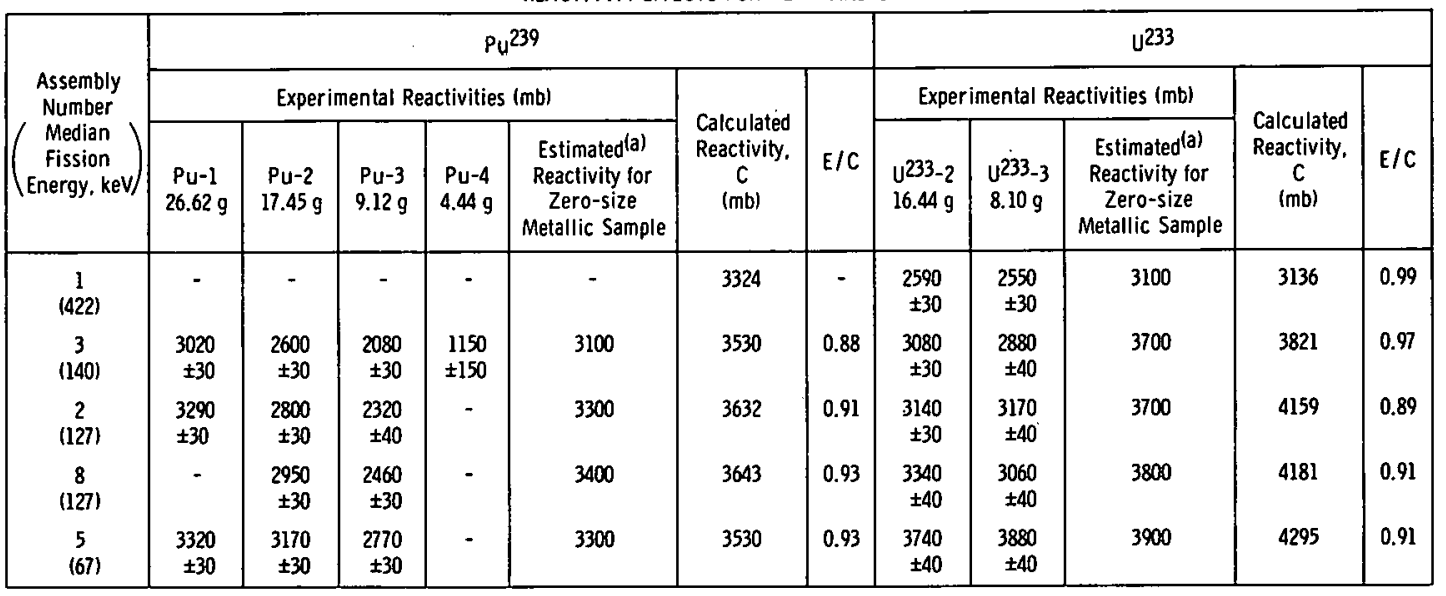

(a) These estimated values may have large errors (see text).

The procedure adopted was to assume that the $\mathrm{Pu}-2(17.45 \mathrm{~g})$ and $\mathrm{U}^{233}-2(16.44 \mathrm{~g})$ reactivities (see Table IX) bore the same relationship to small metallic samples of $\mathrm{Pu}^{239}$ and $\mathrm{U}^{233}$ that the $\mathrm{U}^{235}-2(15.22 \mathrm{~g}$ ) sample did to the estimated reactivity for the zero-size $U^{235}$ sample (Table VIII).

The uncertainties in the estimated $\mathrm{Pu}^{239}$ and $\mathrm{U}^{233}$ zero-sample-size experimental reactivities are unknown but may be large. They have therefore been rounded off to the nearest $100 \mathrm{mb}$.

Table IX shows that neither the $\mathrm{U}^{233}$ nor the $\mathrm{Pu}^{239}$ experimental reactivities agree well with the calculated reactivities, all the experimental values being less than the calculated values. This discrepancy may be due to the uncertainties in deriving the zero-sample-size reactivities. 
The Absorbers $\left(\mathrm{Th}^{232}, \mathrm{U}^{238}, \mathrm{~B}^{10}, \mathrm{Ta}, \mathrm{Mo}\right.$, and $\left.\mathrm{Nb}\right)$

These materials are fairly heavy absorbers, and some of the samples in AETR are sufficiently massive to cause a significant flux depression in the sample. This flux depression increases at lower energies because the absorption cross sections increase with decreasing energy, and the effect is to lower the total flux inside the sample and to harden the neutron spectrum. With absorbers, both of these effects cause the reactivity per atom of a sample of finite size to be less than that in a sample of very small size.

Since the perturbation calculations are valid only for small samples, the experimental data for the absorbers must be corrected, where necessary, for the flux depression effects. In some cases (e.g., $\mathrm{Th}^{232}, \mathrm{U}^{238}$ ), measurements were made with two different sample sizes so that it would appear possible to use these data to extrapolate to give the effects for very small samples. However, the smaller mass samples always contain diluents, and, as we have seen for $\mathrm{U}^{235}$, there appears to be some uncertainty about the subtraction of the reactivity effects of the diluents.

Consequently, a calculated correction has been applied to the reactivity measurements made for samples without diluents. These corrections could be calculated by using a neutron transport computer code or some other fairly exact description of the neutronics of the sample in the reactor, but this would be exceedingly tedious and, unless the cross sections used were known to be correct, there would be no guarantee that the corrections were valid. Since there is ample evidence that the cross sections used are not entirely correct, a simple approximate method has been used to estimate the flux depression effects.

The method used was to calculate for each absorbing sample the flux depression in each energy group caused by a neutron traversing a dis tance equal to the mean chord in the sample. The mean chord was given by 4 (volume of sample)/(surface area of sample). The calculated central spectra were then reduced in each group by the appropriate flux depression, and a hardened spectrum of reduced magnitude was obtained. For example, comparison of the average $B^{10}(n, \alpha)$ cross section in the unperturbed, and in the hardened, depressed spectrum then gives an estimate of the correction.

Although there are obvious shortcomings in this simple method of calculation, many of the absorber data only require small corrections for flux depression effects. For $\mathrm{Th}^{232}, \mathrm{U}^{238}$, and molybdenum, the maximum corrections (in Assembly 5 in all cases) are less than 2\%, and hence uncertainties in the corrections are not important. For niobium, tantalum, and $\mathrm{B}^{10}$, the maximum corrections (again in Assembly 5) are respectively 5, 7 , and $13 \%$, and in these cases, uncertainties in the magnitude of the fluxdepression corrections may introduce additional errors of perhaps 5 to $10 \%$. 
Some allowance for these uncertainties has been made by increasing the errors on the corrected experimental reactivities.

The experimental and calculated reactivity data for the absorbers are compared in Tables $X$ through XII. In almost every case, the experimental reactivity is greater than the calculated value. Since the absorption cross sections that contribute the principal reactivity effect increase with decreasing neutron energy, these results indicate that the calculated spectra are too hard. In many cases, the ratio of experimental and calculated values for any one material are roughly the same for all the reactors. In general, anomalous relative values of experiment and calculation are shown only in Assembly 1. This may reflect the uncertainty discussed earlier in the use of the fundamental-mode method for calculating the spectrum in Assembly 1.

Table $\mathbf{X}$

REACTIVITY EFFECTS OF Th232 AND U238

\begin{tabular}{|c|c|c|c|c|c|c|c|c|c|c|}
\hline \multirow{3}{*}{$\begin{array}{c}\text { Assembly } \\
\text { Number } \\
\left(\begin{array}{c}\text { Median } \\
\text { Fission } \\
\text { Energy, keV }\end{array}\right)\end{array}$} & \multicolumn{5}{|c|}{$T h^{232}$} & \multicolumn{5}{|c|}{$u^{238}$} \\
\hline & \multicolumn{3}{|c|}{ Experimental Reactivity; E (mb) } & \multirow[b]{2}{*}{$\begin{array}{l}\text { Calculated } \\
\text { Reactivity, } \\
\text { C } \\
\text { (mb) }\end{array}$} & \multirow[b]{2}{*}{$E / C$} & \multicolumn{3}{|c|}{ Experimental Reactivity, E (mb) } & \multirow[b]{2}{*}{$\begin{array}{c}\text { Calculated } \\
\text { Reactivity, } \\
\text { C } \\
\text { (mb) }\end{array}$} & \multirow[b]{2}{*}{$E / C$} \\
\hline & $\begin{array}{l}\text { H Th } \\
71.52 \mathrm{~g}\end{array}$ & $\begin{array}{c}\text { L Th } \\
23.22 \mathrm{~g}\end{array}$ & $\begin{array}{l}\text { Estimated } \\
\text { Reactivity for } \\
\text { Zero-size } \\
\text { Metallic Saimple }\end{array}$ & & & $\begin{array}{c}\text { Natural U, } \\
120.5 \mathrm{~g}\end{array}$ & $\begin{array}{l}u^{238}-1 \\
28.28 \mathrm{~g}\end{array}$ & $\begin{array}{l}\text { Estimated(b) } \\
\text { Reactivity for } \\
\text { Zero-size } \\
\text { Metallic Sample }\end{array}$ & & \\
\hline$\underset{(422)}{1}$ & $\begin{array}{r}-98 \\
\pm 1\end{array}$ & $\begin{array}{r}-108 \\
\pm 2\end{array}$ & $\begin{array}{r}-98 \\
\pm 1\end{array}$ & -88 & 1.11 & $\begin{array}{r}+62 \\
\pm 1\end{array}$ & - & $\begin{array}{r}+62 \\
\pm 1\end{array}$ & 131 & 0.47 \\
\hline $\begin{array}{c}3 \\
(140)\end{array}$ & $\begin{array}{r}-260 \\
\pm 4\end{array}$ & $\begin{array}{r}-292 \\
\pm 9\end{array}$ & $\begin{array}{r}-261 \\
\pm 4\end{array}$ & -237 & 1.10 & $\begin{array}{r}-157 \\
\pm 3\end{array}$ & $\begin{array}{r}-173 \\
\pm 8\end{array}$ & $\begin{array}{r}-158 \\
\pm 4\end{array}$ & -116 & 1.36 \\
\hline$\stackrel{2}{2}$ & $\begin{array}{r}-296 \\
\pm 4\end{array}$ & $\begin{array}{r}-326 \\
\pm 8\end{array}$ & $\begin{array}{r}-298 \\
\pm 6\end{array}$ & -271 & 1.10 & $\begin{array}{r}-202 \\
\pm 2\end{array}$ & $\begin{array}{r}-224 \\
\pm 6\end{array}$ & $\begin{array}{r}-204 \\
\pm 4\end{array}$ & -163 & 1.25 \\
\hline $\begin{array}{c}8 \\
(127)\end{array}$ & $\begin{array}{r}-303 \\
\pm 2\end{array}$ & $\begin{array}{r}-301 \\
\pm 5\end{array}$ & $\begin{array}{r}-305 \\
\pm 4\end{array}$ & -272 & 1.12 & $\begin{array}{r}-191 \\
\pm 2\end{array}$ & $\begin{array}{r}-310 \\
\pm 8\end{array}$ & $\begin{array}{r}-193 \\
\pm 4\end{array}$ & -165 & 1.17 \\
\hline $\begin{array}{c}5 \\
(67)\end{array}$ & $\begin{array}{r}-382 \\
\pm 4\end{array}$ & $\begin{array}{r}-439 \\
\pm 6\end{array}$ & $\begin{array}{r}-386 \\
\pm 7\end{array}$ & -312 & 1.24 & $\begin{array}{r}-247 \\
\pm 3\end{array}$ & $\begin{array}{r}-300 \\
\pm 7\end{array}$ & $\begin{array}{r}-251 \\
\pm 6\end{array}$ & -205 & 1.22 \\
\hline
\end{tabular}

(a) Obtained by correcting the $H$ Th data for flux depression. (See text.)

(b) obtained by correcting the natural uranium data for flux depression. (See text.)

Table XI

REACTIVITY EFFECTS OF B ${ }^{10}$ AND Ta

\begin{tabular}{|c|c|c|c|c|c|c|c|c|c|c|}
\hline \multirow{3}{*}{$\begin{array}{c}\text { Assembly } \\
\text { Number } \\
\left(\begin{array}{c}\text { Median } \\
\text { Fission } \\
\text { Energy, keV }\end{array}\right)\end{array}$} & \multicolumn{5}{|c|}{$B^{10}$} & \multicolumn{5}{|c|}{ Tantalum } \\
\hline & \multicolumn{3}{|c|}{ Experimental Reactivity (mb) } & \multirow{2}{*}{$\begin{array}{c}\text { Calculated } \\
\text { Reactivity, } \\
\text { C } \\
\text { (mb) }\end{array}$} & \multirow[b]{2}{*}{$E / C$} & \multicolumn{3}{|c|}{ Experimental Reactivity (mb) } & \multirow{2}{*}{$\begin{array}{c}\text { Calculated } \\
\text { Reactivity, } \\
\text { C } \\
\text { (mb) }\end{array}$} & \multirow[b]{2}{*}{ F.IC } \\
\hline & $\begin{array}{c}\text { Natural } \\
0.82 \mathrm{~g} \\
\mathrm{~B}^{10}\end{array}$ & $\begin{array}{c}\text { Enriched } \\
6.379 \\
\text { B10 }\end{array}$ & $\begin{array}{c}\text { Estimated }{ }^{(a)} \\
\text { Reactivity for } \\
\text { Zero-size Sample }\end{array}$ & & & $104.72 \mathrm{~g}$ & $51.04 \mathrm{~g}$ & $\begin{array}{c}\text { Estimated (b) } \\
\text { Reactivity for } \\
\text { Zero-size Sample }\end{array}$ & & \\
\hline $\begin{array}{c}1 \\
\text { (422) }\end{array}$ & $\begin{array}{r}-950 \\
\pm 10\end{array}$ & $\begin{array}{r}-1070 \\
\pm 10\end{array}$ & $\begin{array}{r}-1110 \\
\pm 35\end{array}$ & -729 & .1 .52 & $\begin{array}{r}-210 \\
\pm 2\end{array}$ & - & $\begin{array}{r}-211 \\
\pm 3\end{array}$ & -98 & 2.15 \\
\hline $\begin{array}{c}3 \\
(140)\end{array}$ & $\begin{array}{r}-2330 \\
\pm 25\end{array}$ & $\begin{array}{r}-1620 \\
\pm 20\end{array}$ & $\begin{array}{r}-1740 \\
\pm 115\end{array}$ & -1386 & 1.26 & $\begin{array}{r}-467 \\
\pm 5\end{array}$ & $\begin{array}{r}-505 \\
\pm 6\end{array}$ & $\begin{array}{r}-477 \\
\pm 13\end{array}$ & -350 & 1.36 \\
\hline $\begin{array}{c}2 \\
\text { (127) }\end{array}$ & $\begin{array}{r}-2880 \\
\pm 30\end{array}$ & $\begin{array}{r}-1840 \\
\pm 20\end{array}$ & $\begin{array}{r}-2000 \\
\pm 140\end{array}$ & -1670 & 1.20 & $\begin{array}{r}-560 \\
\pm 6\end{array}$ & - & $\begin{array}{r}-585 \\
\pm 25\end{array}$ & -454 & 1.29 \\
\hline $\begin{array}{c}8 \\
\text { (127) }\end{array}$ & $\begin{array}{r}-2440 \\
\pm 25\end{array}$ & $\begin{array}{r}-2010 \\
\pm 20\end{array}$ & $\begin{array}{r}-2180 \\
\pm 100\end{array}$ & -1681 & 1.30 & $\begin{array}{r}-564 \\
\pm 6\end{array}$ & - & $\begin{array}{r}-589 \\
\pm 25\end{array}$ & -459 & 1.28 \\
\hline $\begin{array}{c}5 \\
(67)\end{array}$ & $\begin{array}{r}-3400 \\
\pm 35\end{array}$ & $\begin{array}{r}-2660 \\
\pm 30\end{array}$ & $\begin{array}{r}-3000 \\
\pm 180\end{array}$ & -2106 & 1.42 & $\begin{array}{r}-771 \\
\pm 8\end{array}$ & $\begin{array}{r}-842 \\
\pm 9\end{array}$ & $\begin{array}{r}-828 \\
\pm 50\end{array}$ & -644 & 1.29 \\
\hline
\end{tabular}

(a) Obtained by correcting the enriched $B^{10}$ data for flux depression (see text):

(b) obtained by correcting the $104.72 \mathrm{~g}$ tantalum data for flux depression (see text). 
Table XII

REACTIVITY EFFECTS FOR STEEL, Zr, Mo, AND Nb

\begin{tabular}{|c|c|c|c|c|c|c|c|c|c|c|c|c|c|c|}
\hline \multirow{2}{*}{$\begin{array}{c}\text { Assembly } \\
\text { Number } \\
\left(\begin{array}{c}\text { Median } \\
\text { Fission } \\
\text { Energy, keV }\end{array}\right)\end{array}$} & \multicolumn{3}{|c|}{ Steel } & \multicolumn{3}{|c|}{ Zirconium } & \multicolumn{4}{|c|}{ Molybdenum } & \multicolumn{4}{|c|}{ Niobium } \\
\hline & $\begin{array}{c}\text { Experimental } \\
\text { Reactivity, } \\
\text { E (mb) }\end{array}$ & $\begin{array}{l}\text { Calculated } \\
\text { Reactivity, } \\
\text { C (mb) }\end{array}$ & $E-C$ & $\begin{array}{c}\text { Experimental } \\
\text { Reactivity, } \\
\text { E (mb) }\end{array}$ & $\begin{array}{l}\text { Calculated } \\
\text { Reactivity, } \\
\text { C (mb) }\end{array}$ & $E-C$ & $\begin{array}{l}\text { Experimental } \\
\text { Reactivity, } \\
\text { (mb) }\end{array}$ & $\begin{array}{l}\text { Corrected }^{(a)} \\
\text { Experimental } \\
\text { Reactivity, E }\end{array}$ & $\begin{array}{c}\text { Calculated } \\
\text { Reactivity, } \\
\text { C (mb) }\end{array}$ & $E / C$ & $\begin{array}{c}\text { Experimental } \\
\text { Reactivity, } \\
\text { (mb) }\end{array}$ & $\begin{array}{l}\text { Corrected }^{(a)} \\
\text { Experimental } \\
\text { Reactivity, E }\end{array}$ & $\begin{array}{c}\text { Calculated } \\
\text { Reactivity, } \\
\text { C (mb) }\end{array}$ & $E / C$ \\
\hline 1 & 1 & 10 & -9 & - & 15 & - & -19 & -19 & 4 & -4.8 & - & - & -15 & - \\
\hline (422) & \pm 0.2 & & \pm 1 & & & & \pm 1 & \pm 1 & & & & & & \\
\hline 3 & -19 & -9 & -10 & -31 & -15 & -16 & -104 & -104 & -73 & 1.42 & -133 & -135 & -122 & 1.11 \\
\hline$(140)$ & \pm 2 & & \pm 2 & \pm 3 & & \pm 3 & \pm 2 & \pm 2 & & & \pm 2 & \pm 4 & & \\
\hline 2 & -28 & -11 & -17 & -46 & -19 & -27 & -121 & -122 & -93 & 1.31 & - & - & -172 & - \\
\hline (127) & \pm 2 & & \pm 2 & \pm 3 & & \pm 3 & \pm 2 & \pm 3 & & & & & & \\
\hline 8 & -18 & -11 & -7 & -35 & -19 & -16 & -108 & -109 & -94 & 1.16 & -155 & -159 & -174 & 0.91 \\
\hline (127) & \pm 1 & & \pm 1 & \pm 2 & & \pm 2 & \pm 2 & \pm 3 & & & \pm 2 & \pm 5 & & \\
\hline 5 & -13 & -10 & -3 & -17 & -20 & +3 & -164 & -166 & -119 & 1.39 & -344 & -360 & -271 & 1.33 \\
\hline (67) & \pm 1 & & $\pm l$ & \pm 2 & & \pm 2 & \pm 2 & \pm 4 & & & \pm 4 & \pm 16 & & \\
\hline
\end{tabular}

(a)Corrected for flux depression (see text). 
The Scatterers $\left(\mathrm{Z}_{\mathrm{r}}\right.$, Steel, $\mathrm{C}, \mathrm{Na}$, and $\left.\mathrm{Al}\right)$

In all of these materials, scattering is an important contributor to the reactivity effect. With carbon, scattering is essentially the sole con-' tributor since absorption is very small. Absorption is not large in any case, so that flux-depression effects have been ignored, and no corrections have been applied to the experimental data.

The experimental and calculated reactivities are compared in Tables XII and XIII, and it can been seen that the agreement is not good. The data for $\mathrm{C}, \mathrm{Al}$, and $\mathrm{Na}$ in Table XIII are listed in order of increasing softness of the adjoint spectrum, i.e., decreasing fertile/fissile ratio, since scattering effects are expected to be sensitive to the shape of the adjoint spectrum [Davey $(3)]$.

Table XIII

REACTIVITY EFFECTS OF CARBON, SODIUM, AND ALUMINUM

\begin{tabular}{|c|c|c|c|c|c|c|c|c|c|}
\hline \multirow{2}{*}{$\begin{array}{c}\text { Assembly } \\
\text { Number } \\
\left(\begin{array}{c}\text { Fertile } \\
\text { Fissile } \\
\text { Ratio }\end{array}\right)\end{array}$} & \multicolumn{3}{|c|}{ Carbon } & \multicolumn{3}{|c|}{ Sodium } & \multicolumn{3}{|c|}{ Aluminum } \\
\hline & $\begin{array}{c}\text { Experimental } \\
\text { Reactivity, } \\
E \text { (mb) }\end{array}$ & $\begin{array}{c}\text { Calculated } \\
\text { Reactivity, } \\
C \text { (mb) }\end{array}$ & $E-C$ & $\begin{array}{c}\text { Experimental } \\
\text { Reactivity, } \\
\text { E (mb) }\end{array}$ & $\begin{array}{c}\text { Calculated } \\
\text { Reactivity, } \\
\text { C (mb) }\end{array}$ & $E-C$ & $\begin{array}{c}\text { Experimental } \\
\text { Reactivity, } \\
\text { E (mb) }\end{array}$ & $\begin{array}{c}\text { Calculated } \\
\text { Reactivity, } \\
\text { C (mb) }\end{array}$ & $E-C$ \\
\hline $\begin{array}{c}8 \\
(9.0)\end{array}$ & $\begin{array}{r}-12 \\
\pm 1\end{array}$ & -1 & $\begin{array}{r}-11 \\
\pm 1\end{array}$ & $\begin{array}{l}18 \\
\pm 4\end{array}$ & -11 & $\begin{array}{l}39 \\
\pm 4\end{array}$ & $\begin{array}{l}15 \\
\pm 1\end{array}$ & -5 & $\begin{array}{l}20 \\
\pm 1\end{array}$ \\
\hline $\begin{array}{c}2 \\
(8.9)\end{array}$ & $\begin{array}{r}-44 \\
\pm 2\end{array}$ & -1 & $\begin{array}{r}-43 \\
\pm 2\end{array}$ & $\begin{array}{r}-17 \\
\pm 6\end{array}$ & -10 & $\begin{array}{l}-7 \\
\pm 6\end{array}$ & $\begin{array}{r}24 \\
\pm 2\end{array}$ & -5 & $\begin{array}{l}29 \\
\pm 2\end{array}$ \\
\hline $\begin{array}{c}5 \\
(7.0)\end{array}$ & $\begin{array}{r}7 \\
\pm 1\end{array}$ & 3 & $\begin{array}{r}4 \\
\pm 1\end{array}$ & $\begin{array}{l}36 \\
\pm 4\end{array}$ & -17 & $\begin{array}{l}53 \\
\pm 4\end{array}$ & $\begin{array}{l}-8 \\
\pm 2\end{array}$ & -2 & $\begin{array}{l}-6 \\
\pm 2\end{array}$ \\
\hline$\stackrel{3}{(4.0)}$ & $\begin{array}{r}-28 \\
\pm 2\end{array}$ & 4 & $\begin{array}{r}-32 \\
\pm 2\end{array}$ & $\begin{array}{r}-25 \\
\pm 6\end{array}$ & -1 & $\begin{array}{r}-24 \\
\pm 6\end{array}$ & $\begin{array}{r}-19 \\
\pm 2\end{array}$ & -2 & $\begin{array}{r}-17 \\
\pm 2\end{array}$ \\
\hline $\begin{array}{c}1 \\
(0.07)\end{array}$ & $\begin{array}{l}46 \\
\pm 2\end{array}$ & 36 & $\begin{array}{r}10 \\
\pm 2\end{array}$ & - & 27 & - & $\begin{array}{r}9 \\
\pm 1\end{array}$ & 16 & $\begin{array}{l}-7 \\
\pm 1\end{array}$ \\
\hline
\end{tabular}

In general, the scatterer data indicate that the calculated adjoint spectra are too hard.

Comparison with ZPR-III Measurements

A comparison between experimental and calculated AETR and ZPR-III reactivity data is summarized in Table XIV. The ZPR-III experience indicated that the ratio of experiment to calculation for any one absorber was approximately the same for all the reactors examined, and consequently, it was permissible to derive a mean value for this ratio for each material. The AETR data do not conflict with this experience; hence, Table XIV lists mean values. 
Table XIV.

SUMMARY OF REACTIVITY DATA

\begin{tabular}{|c|c|c|c|}
\hline Material & $\begin{array}{c}\text { AETR } \\
\text { (Mean Value) }\end{array}$ & $\begin{array}{c}\mathrm{ZPR}-\operatorname{III}(\mathrm{a}) \\
(\text { Mean Value) }\end{array}$ & $\begin{array}{l}\text { Agreement } \\
\text { between AETR } \\
\text { and ZPR-III }\end{array}$ \\
\hline $\mathrm{U}^{233}$ & $E / C=0.93$ & $E / C=0.98$ & $\begin{array}{l}\text { Possibly within } \\
\text { experimental errors }\end{array}$ \\
\hline $\mathrm{Pu}^{239}$ & $E / C=0.91$ & $E / C=0.97$ & $\begin{array}{l}\text { Possibly within } \\
\text { experimental errors }\end{array}$ \\
\hline $\mathrm{U}^{238}$ & $\mathrm{E} / \mathrm{C}=1.25(\mathrm{~b})$ & $E / C=1.10$ & $\begin{array}{l}\text { Possibly within } \\
\text { experimental errors }\end{array}$ \\
\hline $\mathrm{Th}^{232}$ & $E / C=1.13$ & $E / C=0.94$ & No \\
\hline$B^{10}$ & $\mathrm{E} / \mathrm{C}=1.34$ & $E / C=1.39$ & Yes \\
\hline $\mathrm{Ta}$ & $E / C=1.31(b)$ & $\mathrm{E} / \mathrm{C}=1.22$ & $\begin{array}{l}\text { Possibly within } \\
\text { experimental errors }\end{array}$ \\
\hline $\mathrm{Nb}$ & $E / C=1.12$ & $E / C=1.06$ & $\begin{array}{l}\text { Possibly within } \\
\text { experimental errors }\end{array}$ \\
\hline Mo & $E / C=1.32^{(b)}$ & $E / C=0.96$ & No \\
\hline $\mathrm{Zr}$ & $E<C$ & $E \approx C$ & No \\
\hline Steel & $\mathrm{E}<\mathrm{C}$ & $E \approx C$ & No \\
\hline $\mathrm{Al}$ & \multirow{3}{*}{\multicolumn{3}{|c|}{ Roughly the same trends indicated in both reactors. }} \\
\hline $\mathrm{Na}$ & & & \\
\hline C & & & \\
\hline
\end{tabular}

(a) The ZPR-III data of Davey, $(3,6)$ which were originally normalized to $\mathrm{Pu}^{239}$, have been renormalized to $\mathrm{U}^{235}$. (Also see text for other comments.)

(b) Excluding data for Assembly l, since these appear to be anomalous.

The ZPR-III data differ somewhat from those originally published. $(3,6)$ First, the original data, which were normalized to $\mathrm{Pu}^{239}$, have been renormalized to $U^{235}$. Second, the experimental reactivities of all materials except $\mathrm{U}^{233}$ and $\mathrm{Pu}^{239}$ have been increased by $7 \%$ to allow for sample size effects in $\mathrm{U}^{235}$ that were previously ignored. The $\mathrm{U}^{233}$ and $\mathrm{Pu}^{239}$ experimental reactivities have been decreased by $2 \%$ (relative to $\mathrm{U}^{235}$ because of sample-size corrections. Third, none of the absorber data has 
been corrected for flux-depression effects as has been done with the AETR data. This onission probably does not affect the ZPR-III absorber data appreciably since many of the ZPR-III assemblies have quite hard spectra in which flux-depression effects would be small.

The ZPR-III data should therefore be comparable to the AETR results.

The AETR and ZPR-III data for the fuels $\mathrm{U}^{233}$ and $\mathrm{Pu}^{239}$ do not agree very well; but in view of the uncertainty in deriving the small sample AETR reactivities, the difference could well be within experimental error.

The AETR and ZPR-III $U^{238}$ data also do not agree too well, but the $\mathrm{ZPR}$-III individual $U^{238}$ measurements show quite wide variations in $\mathrm{E} / \mathrm{C},(3,6)$ and the differences between AETR and ZPR-III may be within experimental errors.

In the case of $\mathrm{Th}^{232}$, there is a well-defined discrepancy in the data obtained from the two reactors. In $\mathrm{ZPR}-\mathrm{III}$, the $\mathrm{E} / \mathrm{C}$ ratios show quite small variations over the range of the assemblies, and the same is true in AETR (Table $\mathrm{X}$ ), but the mean values of $\mathrm{E} / \mathrm{C}$ in the two reactors differ by $20 \%$. This appears to be a clear-cut experimental discrepancy.

The $\mathrm{B}^{10}$ data in ZPR-III and AETR are in excellent agreement, and the tantalum and niobium probably agree to within experimental errors, but there is a strong discrepancy for the remaining absorber, molybdenum.

The zirconium and steel data in the two reactors are not in agreement in the two reactors, and this would appear to be an experimental discrepancy.

For the scatterers, carbon, sodium, and aluminum, the data in the two reactors indicate similar trends.

In summary, the AETR and ZPR-III reactivity data are in good agreement only for $\mathrm{B}^{10}$. However, for $\mathrm{U}^{233}, \mathrm{Pu}^{239}, \mathrm{U}^{238}, \mathrm{Ta}, \mathrm{Nb}, \mathrm{Al}, \mathrm{Na}$, and $\mathrm{C}$, the discrepancies in the data obtained in the two reactors may be within experimental errors.

For $\mathrm{Th}^{232}$, molybdenum, zirconium, and steel, the experimental reactivities in AETR and $Z P R-I I I$ are in disagreement.

However, the AETR and ZPR-III absorber and scatterer reactivities indicate the same general conclusion that the calculated real and adjoint spectra are too hard. 
The variation of importance with energy was measured using six radioactive sources that emit neutrons of different energies. The sources used were $\mathrm{Po}-\mathrm{Be}, \mathrm{Po}_{\mathrm{O}} \mathrm{B}^{11}$, Mock Fission, $\mathrm{Po}-\mathrm{CaF}_{2}, \mathrm{Po}_{\mathrm{O}} \mathrm{Li}^{7}$, and $\mathrm{Sb}-\mathrm{Be}$. With the exception of $\mathrm{Sb}-\mathrm{Be}$, each source emits neutrons over a moderate range of energies. The relative strength of the sources was measured using a manganese sulphate bath, (2) and the variation of importance with energy was measured by analyzing the reactor power oscillations produced by periodically interchanging each source and its inactive dummy at the center of the test region.

The measured and calculated importances are compared in Table XV.

Table XY

CALCULATED AND MEASURED IMPORTANCES

\begin{tabular}{|c|c|c|c|c|c|c|c|c|c|}
\hline \multirow{2}{*}{$\begin{array}{l}\text { Assembly } \\
\text { Number }\end{array}$} & \multirow{2}{*}{$\begin{array}{l}\text { Assembly } \\
\text { Type }\end{array}$} & \multicolumn{2}{|c|}{$\begin{array}{l}\text { Po-Be, Po-Bll Mock Fission } \\
(4490 \mathrm{keV}, 2940 \mathrm{keV}, 3150 \mathrm{keV})\end{array}$} & \multicolumn{2}{|c|}{$\begin{array}{l}\text { Po-Caf2 } \\
\text { (1380 keV) }\end{array}$} & \multicolumn{2}{|c|}{$\begin{array}{c}\text { Po- } \mathrm{Li}^{7} \\
(460 \mathrm{keV})\end{array}$} & \multicolumn{2}{|c|}{$\begin{array}{c}\mathrm{Sb}-\mathrm{Be} \\
(39 \mathrm{keV})\end{array}$} \\
\hline & & $\begin{array}{l}\text { Experimental } \\
( \pm 0.02)^{(a)}\end{array}$ & Calculated $^{(b)}$ & $\begin{array}{l}\text { Experimental } \\
( \pm 0.02)\end{array}$ & Calculated & $\begin{array}{l}\text { Experimental } \\
\quad( \pm 0.02)\end{array}$ & Calculated & $\begin{array}{l}\text { Experimental } \\
\quad( \pm 0.02)\end{array}$ & Calculated \\
\hline 1 & $\mathrm{U}^{235}$, no Th & $1.02,1.00,1.00$ & 1.00 & 0.86 & 1.02 & 1.02 & 1.07 & 1.34 & 1.34 \\
\hline 3 & $u^{235}$ plus Th & $1.00,0.98,1.00$ & 1.00 & 0.86 & 0.96 & 0.90 & 0.95 & 0.72 & 0.97 \\
\hline 5 & $\begin{array}{l}U^{233} \text { plus Th } \\
\text { (Th/U233) }=7\end{array}$ & $0.97,0.96,1.00$ & 1.00 & 1.00 & 0.98 & 0.98 & 0.99 & 0.93 & 1.03 \\
\hline 2 & $\begin{array}{l}U^{233} \text { plus Th } \\
\left(T h / U^{233}\right)=9\end{array}$ & $1.00,1.00,1.00$ & 1.00 & 0.93 & 0.96 & 0.94 & 0.94 & 0.65 & 0.95 \\
\hline 8 & $\begin{array}{l}U^{233} \text { plus Th } \\
\left(T h / U^{233}\right)=9\end{array}$ & $1.00,1.02,1.00$ & 1.00 & 0.99 & 0.97 & 0.98 & 0.94 & 0.83 & 0.95 \\
\hline 9 & $\begin{array}{l}U^{233} \text { plus Th } \\
\left(T h / U^{233}\right)=9\end{array}$ & $0.99,1.01,1.00$ & 1.00 & 1.00 & 0.96 & 0.98 & 0.94 & 0.76 & 0.93 \\
\hline
\end{tabular}

(a) The experimental values are normalized to 1.00 for the Mock Fission source.

(b) The calculations are normalized to 1.00 for these neutrons.

The $\mathrm{Po}-\mathrm{Be}, \mathrm{Po}-\mathrm{B}^{11}$, and Mock Fission sources have similar energies, and all are compared with the mean of the calculated importances in Groups 1 and 2 (see Table II). The Po-CaF $2, \mathrm{Po}_{-} \mathrm{Li}^{7}$, and $\mathrm{Sb}-\mathrm{Be}$ measurements are compared, respectively, with the mean calculated importances in Groups 3 and 4, 5 and 6 , and 10 and 11 . The measurements are normalized to unity for the Mock Fission source, and the calculations are also normalized to unity at this energy.

The neutron importance at any energy is largely proportional to the average value of

$$
\frac{\nu \sigma_{F}}{1+\alpha}
$$

for the core materials at that energy, and the importance, therefore, depends upon both the type of fissile and fertile materials used. The nuclear 
characteristics of the other materials are of lesser importance. We may, therefore, infer the accuracy of some of the nuclear data for $\mathrm{U}^{233}, \mathrm{U}^{235}$, and thorium from these measurements.

The accuracy of these inferences depends directly upon the accuracy of the calibration of the sources.

Assembly 1 (U $\mathrm{U}^{235}$, No Thorium)

For Assembly 1 , since neither $\nu$ or $\alpha$ for $U^{235}$ vary rapidly over the energy $r$ ange of interest, the importance is largely proportional to $\sigma_{F}$ for $\mathrm{U}^{235}$. The agreement between experiment and calculation is generally good; i.e., the assumed variation of $\sigma_{F}$ for $U^{235}$ is generally good. However, the measurement with $\mathrm{Po}-\mathrm{CaF}_{2}$ would appear to indicate that the assumed value of $\sigma_{F}$ for $\mathrm{U}^{235}$ is about $15 \%$ too large at about $1400 \mathrm{keV}$.

As sembly 3 (U ${ }^{235}$ Plus Thorium)

For Assembly 3, the measurement with Po-CaF 2 supports the apparent conclusion in Assembly 1 that the assumed $\sigma_{F}$ for $U^{235}$ is too large at about $1400 \mathrm{keV}$. The $\mathrm{Sb}-\mathrm{Be}$ measurement indicates that the assumed capture cross section of thorium at about $40 \mathrm{keV}$ is too low. (Note that errors in the $\mathrm{U}^{235}$ fission cross section would not appear to be the cause of the discrepancy at $40 \mathrm{keV}$ because the $\mathrm{Sb}-\mathrm{Be}$ calculations and measurements agree in Assembly 1.)

Assemblies 5, 2, 8, and 9 (U ${ }^{233}$ Plus Thorium)

For these assemblies, agreement is good except for $\mathrm{Sb}-\mathrm{Be}$, where there is the same disagreement as in Assembly 3. This again indicates that the assumed capture cross section of thorium is too low at about $40 \mathrm{keV}$. The variation of measurements with $\mathrm{Sb}-\mathrm{Be}$ in Assemblies.2, 8, and 9 may possibly be some indication of experimental uncertainties, since the calculated importances for these assemblies are closely similar.

\section{CONCLUSIONS}

The AETR fission ratios show the same broad trends as those measured in $Z P R$-III in that the ratios measured relative to $U^{235}$ are lower than the calculated values, but the agreement between the ratios obtained in the two reactors is not good. In particular, there are differences of 6 and $12 \%$, respectively, for the $U^{236} / U^{235}$ and $U^{234} / U^{235}$ ratios. In general, the fission ratios indicate that the calculated spectra are too hard.

The AETR reactivity data generally show the same conclusion as the ZPR-III reactivity analysis that the calculated real and adjoint spectra are 
too hard. The AETR and ZPR-III data are in good agreement only for $\mathrm{B}^{10}$. The discrepancies between the results of the two reactors for $\mathrm{U}^{233}, \mathrm{Pu}^{239}$, $\mathrm{U}^{238}, \mathrm{Ta}, \mathrm{Nb}, \mathrm{Al}, \mathrm{Na}$, and $\mathrm{C}$ may be within experimental errors, but the discrepancies for $\mathrm{Th}^{232}, \mathrm{Mo}, \mathrm{Zr}$, and steel appear to be outside the range of experimental error.

The AETR measured importances indicate that the assumed $\sigma_{F}$ for $\mathrm{U}^{235}$ is too large at about $1400 \mathrm{keV}$ and the assumed $\sigma_{\mathrm{C}}$ for thorium is too small at about $40 \mathrm{keV}$. There are no ZPR-III data that can be compared with the AETR source importance measurements.

\section{ACKNOW LEDGMENTS}

Valuable comments on an early draft of this report were made by S. G. Carpenter of Atomics International. R. G. Palmer suggested the method used for the flux-depression calculations for the reactivity data, and Elvera Slansky carried out many of the computations. 


\section{REFERENCES}

1. Atomics International Staff, AI-7614 (1962).

2. Atomics International Staff, AI-8549 (1963).

3. W. G. Davey, Nucl. Sci. Eng. 19, 259-273 (1964).

4. W. G. Davey, k-Calculations for 22 ZPR-III Assemblies Using ANL Cross-section Set 635, ANL-6570(1962).

5. W. G. Davey, A Critical Comparison of Measured and Calculated Fission Ratios for ZPR-III Assemblies; ANL-6617 (1962).

6. W. G. Davey, A Comparison of Experimental and Calculated Prompt Neutron Lifetimes and Central Reactivity Coefficients in ZPR-III Assemblies and Their Relationship to Other Reactor Parameters, ANL-6682 (1963).

7. S. Yiftah, D. Okrent, and P. A. Moldauer, Fast Reactor. Cross Sections, Pergamon Press, New York (1960).

8. A. V. Campise, Proc. Seminar on Physics of Fast and Intermediate Reactors sponsored by IAEA, Vienna, III, SM-18/61, 335-354 (1962).

9. W. G. Davey and. P. I. Amundson, A Re-evaluation of Fission Ratios Measured in ZPR-III Assemblies, ANL-6941 (1964).

10. A. L. Hess, Argonne National Laboratory, unpublished.

11. Reactor Development Program Progress Report, December 1963 (p. 6), ANL-6810.

12. R. D. Smith et al.; Fast Reactor Physics Including Results from U.K. Zero Power Reactors, 1964 Geneva Conference on the Peaceful Uses of Atomic Energy, Paper P/166 (1964). 